RESEARCH NOTES

\title{
The Views of University Students About the Achievements and Motivations of the Distance Education Process During the Pandemic Period
}

Las opiniones de los estudiantes universitarios sobre los logros y las motivaciones del proceso de educación a distancia durante el período pandémico

\section{Şebnem Güldal KAN*}

Near East University

Orchid Id: 0000-0002-8241-0868

Çilem Çaltıkuşu

Near East University

Orchid id: 0000-0001-6974-6036

Şeniz Şensoy

Near East University

Orchid id: 0000-0002-3896-6463

Received 09-08-20 Revised 10-10-20

Accepted 12-12-20 On line 03-17-21

* Correspondence

Citation:

Email: Sebnem.guldal@neu.edu.tr

Şebnem Güldal KAN, Çilem Caltıkușu, ŞenizŞensoy. (2021). The Views of University Students About the Achievements and Motivations of the Distance Education Process During the Pandemic Period. Propósitos y Representaciones, 9 (SPE3), e1165. Doi: http://dx.doi.org/10.20511/pyr2021.v9nSPE3.1165 


\begin{abstract}
The aim of this study is to examine the views of students about the achievements and motivations of thedistance education processes in universities during the pandemic period. The working group consists of 68 prospective teachers who continue their undergraduate programs in different departments of a private university in Northern Cyprus in the 2019-2020 spring academic year. All these participantsarestudying at thevariousdepartments of theFaculty of Education as 17 are in Preschool Education, 28 in PrimaryEducationMathematics, 6 in PrimaryEducation, 1 in HistoryTeaching, 12 in Special Needs Education, 4 of them arestudying in Guidance and Psychological Counseling. The study is a qualitative study and the design of the study is determined as a case study. 42 female and 26 male teacher candidates participated in the study group. The majority of the participants are prospective teachers studying in their final year at university. While choosing the participants, easily accessible case sampling from purposeful sampling type was used. A Semi-structured interview form was used as a toolfordata collection. Later, the opinions of the experts were obtained and the interview questions were re-arranged accordingly and applied to the participants. As a result of the research, it was concluded that the psychological trauma experienced by teacher candidates during distance education at thepandemicperiodaffects both the success and motivation of their lessons.
\end{abstract}

Keywords: Pandemic period, University, Distance Education, Success, Motivation.

\title{
Resumen
}

El objetivo de este estudio es examinar las opiniones de los estudiantes sobre los logros y motivaciones de los procesos de educación a distancia en las universidades durante el período pandémico. El grupo de trabajo está formado por 68 futuros profesores que continúan sus programas de pregrado en diferentes departamentos de una universidad privada en el norte de Chipre en el año académico de primavera 2019-2020. Todos estos participantes estudian en los distintos departamentos de la Facultad de Educación ya que 17 están en Educación Infantil, 28 en Educación Primaria en Matemáticas, 6 en Educación Primaria, 1 en Docencia en Historia, 12 en Educación Especial, 4 de ellos en Orientación y Consejería Psicológica. El estudio es un estudio cualitativo y el diseño del estudio se determina como un estudio de caso. En el grupo de estudio participaron 42 mujeres y 26 hombres candidatos a maestros. La mayoría de los participantes son futuros profesores que estudian en su último año en la universidad. Al elegir a los participantes, se utilizó un muestreo de casos de fácil acceso a partir del tipo de muestreo intencional. Se utilizó un formulario de entrevista semiestructurada como herramienta para la recopilación de datos. Posteriormente, se obtuvieron las opiniones de los expertos y las preguntas de la entrevista se reorganizaron en consecuencia y se aplicaron a los participantes. Como resultado de la investigación, se concluyó que el trauma psicológico experimentado por los candidatos a maestros durante la educación a distancia en el período pandémico afecta tanto el éxito como la motivación de sus lecciones.

Palabras clave: Periodo pandémico, Universidad, Educación a distancia, Éxito, Motivación.

\section{Introduction}

With the beginning of the millennium, we entered the process of transition to the information society. The use of developing and changing information technologies has been assumed by authors such as Naisbitt and Toffler related to research in different ways. At the very beginning of 2020, we encountered the pandemic period with the threat of a virus allegedly originated in Wuhan, China. The epidemic of this virus quickly spread around the world. With the transition to the pandemic period, it affected the subjective and social lives of people and different measures were taken. At the beginning of these measures, actions taken by states or local administrations such as flight bans, quarantine, martial law, and regulations for the protection of social distance were increased. To slow down the pandemic, people living in certain masses stay in the house temporarily, to limit the movement as much as possible, it has become more dominant than the approach to increase the community's immune system and has been adopted as a common practice in all countries (Telli and Altun, 2020).Thevirusbeganto be seen in Turkey and in theTurks of theRepublic of Northern Cyprus 
on March 11, 2020.Immediatemeasurementsweretakencoveringseveralsectorsby relevant institutions of the state as soon as the first case was detected in Turkey. In this context, the Higher Education Board (YOK) in Turkey to slow down the spread of the virus, to prevent the victimization of education, on March 26, 2020 announcedthatnoclasseswould be done facetofacein thehighereducation at springsemesterduring 2019-2020 academicyear. So it came to distance education agenda in Turkey (YOK, 2020b). Distance education has become a compulsory application, which must be implemented quickly regardless of the infrastructure, in order to manage the process effectively and to prevent the suffering of students such as not being able to graduate and losing semesters. With this application, it quickly took place in all education levels on the preliminary prediction of the deficit and negative impact experienced at all education levels. (Brooks et al., 2020; Owusu-Fordjour, Sahu, 2020). Thus, as the COVID 19 pandemic period has been experienced, we have switched to a compulsory infrastructure in the distance education system by electronizing public administrations, universities and schools, and digitalizing their administrative processes (Sarıtaşand Barutçu, 2020).

Considering the studies dealing with distance education, the results of the studies conducted in Akdemir (2011) showed that distance education is preferred in our Higher Education, while achieving, only the number of programs and students in the 2014-2015 and 2015-2016 academic years could be reached at the master's level. As Yildiz and Cakmak (2021) notes that banks, ministries, universities prefer distance education in personnel training. Banks provide interactive trainings and exams to their employees through distance education systems. Ministries provide inservice training to their personnel through distance education. (Yildiz \& Cakmak, 2021) For Berigel, (2017) skills and experience of staff determines growth speed of distance education and quality of distance education. In their research on the other hand Tuncer and Bağdır (2017), the students criticized distance learning as it may be suitable for some courses, as they may be suitable for some courses, and evaluated the instructors working in distance education as irrelevant and sincere. In a similar finding, Tuncer and Tanaş (2011) stated in their study that distance education is not suitable for science fields, rather pessimistic mood in terms of learning environment, failures due to attendance and limited interaction, and individual approaches will decrease the efficiency expected from learning activities.

For this purpose, descriptive content analysis will be carried out in the qualitative research method to evaluate the opinions of the University Students on how the distance education process affects their success and motivation. For this purpose, answers to the following questions were sought:

1. How do the students studying the pandemic period evaluate at the university?

2. How are the levels of achievements of university students' success in distance learning related to distance education affected during the pandemic period?

3. How does the workload given to the students by the faculty member about distance education affect their motivation during the pandemic period?

\section{Method}

\section{Research model}

The model of the study is qualitative and the pattern is thecase study. The reason for choosing this pattern is that during the pandemic period, the opinions of the students about the achievements and motivations of the distance education process in the universities were affected and the desires to be analyzed and analyzed. The case study is an approach that allows us to focus on a particular situation in depth.

The holistic single state pattern exists in three cases: First, if there is a well-formulated theory in the middle, this pattern has been used to confirm or refute it. If the latter does not comply with the general standards, a holistic single state pattern can be used in an overly contradictory and unique case study. Finally, a holistic single state pattern can be used where no one has ever worked or reached (Yıldırım\& Şimşek, 2013). 


\section{Working group}

The study group consists of 68 students studying in different departments of the Near East University in the Turkish Republic of Northern Cyprus and Atatürk Faculty of Education during the COVID19 pandemic period in the 2019-2020 spring academic year. Of the students, 17 are in Pre-school Education, 28 in PrimaryEducation mathematics, 6 in PrimaryClassroomteacher Education, 1 in History teaching, 14 in Special Needs Education, 4students studying in the Department of Guidance and Psychological Counseling. The study is a qualitative study and the design of the study is determined as a case study. 42 female and 26 male students participated in the study group. The majority of the participants are prospective teachers studying in the last year'sgraduate program. Purposeful sampling was used when determining the participants.

\section{Data Collection Tool, Data Collection, and Analysis}

Interview form was preferred as the data collection tool since the main data collection tool was the interview in case studies. A semi-structured interview form developed by the researcher was used in the data collection phase. In a structured interview, questions are determined in advance, and data is tried to be collected with these questions (Karasar, 1998). The questions have been prepared in a way that can clearly reveal the opinions and motivations of university students about distant education during the COVID19 pandemic period. The statements in the interview form consist of 8 questions prepared for university students studying at the university for their success and motivation in the distance education process. Due to the situation, due to the curfew we were in during the pandemic period, questions were prepared in the Google Form, and Google drive prevented the loss of data by writing down the qualitative data obtained by the uploaded responses and was also limited to its analysis by descriptive and content analysis method. The data summarized and interpreted in descriptive analysis require a more in-depth analysis than content analysis and reaching concepts and themes that explain this data (Yıldırım\& Şimşek, 2013).

At the end of this study, the validity of the question items was determined. It was concluded that the interview questions provided the desired data and the data collection process was initiated.

\section{Result}

The themes obtained from the opinions of the things can be tabulated and interpreted together with the frequency distributions. In the study, it was designed to plan success achievements and motivations in operations in distance education at universities during the Pandemic period. The findings obtained from the opinions of those studying at this intended University will be read in Table 1.

Table 1. Opinions about the pandemic period

\begin{tabular}{|c|c|c|}
\hline Theme & N & \% \\
\hline SoTiring & 6 & 9 \\
\hline BadPeriod & 20 & 29 \\
\hline Financial Problems & 4 & 6 \\
\hline Disease & 4 & 6 \\
\hline Unconsciousness of public & 1 & 1 \\
\hline SpirituallyCorrosive & 19 & 28 \\
\hline Ifschoolsopen & 4 & 6 \\
\hline New life philosophy & 3 & 4 \\
\hline Patiance & 2 & 3 \\
\hline War & 5 & 7 \\
\hline Total & 68 & 100 \\
\hline
\end{tabular}


When Table 1 is analyzed, while $29 \%$ of university students participating in the study are bad terms, $1 \%$ made opinions about the unconsciousness of the public.

Below arethe details of the opinions of university students involved in the study about the pandemic period:

STD1: «A New Philosophy»

STD32: "It is a very bad situation»

STD54: "In this period, we were psychologically damaged because our health was in danger."

Table 2. Success levels of university students in terms of learning about distance education during the pandemic period

\begin{tabular}{|c|c|c|}
\hline Theme & N & \% \\
\hline Bad & 26 & 38 \\
\hline Good & 22 & 32 \\
\hline No idea & 1 & 1 \\
\hline Avarage & 13 & 19 \\
\hline Suspicious & 6 & 100 \\
\hline Total & 68 & 9 \\
\hline
\end{tabular}

When Table 2 is analyzed,38\% of the achievement levels of the university students participating in the study in terms of distance learning in terms of learning are stated as "Bad", while $1 \%$ made opinions about No Idea.

Below arethe details of the opinions of university students involved in the study regarding their levels of success in terms of distance education:

STD26: "We are overwhelmed personally, distance learning assignment, quiz, project. I don't want to see it, I think it's not good. It is ridiculous to have a lot of things done and waste our time or even days for 10 points. explained"

STD28: 'I am very successful, I have good grades but I have homework that is not

STD37 «I fulfill my responsibilities as long as my possibilities permit, I try to utilize at the maximum level, but I do not think that we can achieve the efficiency we get at school, even though we try hard.»

STD38 «It provides a very productive education, it enables us to reinforce the subjects with the way the lesson runs and the homework it gives.

Table 3. Motivation of University students about distance education in the period of pandemic

\begin{tabular}{|c|c|c|}
\hline Theme & N & \% \\
\hline My motivation is falling & 24 & 35 \\
\hline My psychologygetdisturb & 20 & 29 \\
\hline VeryGood & 4 & 6 \\
\hline Not affect & 6 & 9 \\
\hline Affecting & 14 & 21 \\
\hline Total & 68 & 100 \\
\hline
\end{tabular}

Table 3. When analyzed, 35\% of university students participating in the study stated that "My motivation is falling" while $6 \%$ of them stated that their motivation is very good. 
Below arethe details of the opinions of university students involved in the study about their motivations regarding distance education:

STD2.: «Very intense homework is being given, I am psychologically disturbed»

STD7: 'Yes, it lowers our motivation because every teacher almost I took the video, I told him, he goes in the style of the students.

STD12: "In this difficult process, when we have homework on top of each other, we sometimes have difficulties to do it. Unfortunately, our bad mood is getting worse when we say homework was a test, unfortunately. »

STD18: I do not understand why some of our teachers give more homework than they need, do thequiz, do theexam, I think they need to think more about student motivation.

STD30: "No, it certainly does not affect me, I think it adds a lot to me"

\section{Conclusion, Discussion, And Suggestion}

In this study, it was concluded that the psychological trauma experienced by university students during distance education during pandemic affects both the success and motivation of their lessons.

Opinions regarding the evaluation of the sub-problem questions of the opinions of the students about how the distance education process affects their success and motivation;

Most of the students related to the pandemic period were found to be based on the conclusion that they were badly and spiritually wornout. Similar to this study, in their study, Çetin and Özlem (2020) have made a difference both on loneliness and psychological resilience in the study of students living withtheir familiesortheclose environment due to Covid-19, their thoughts about their future, meeting their basic needs in the future. In his research Erarslan(2014), found that positive self-perception and positive future perception have a partial mediating role between psychological resilience and life satisfaction.

In the second sub-dimension of the study, they expressed their opinions about the poor achievement levels of university students in terms of learning about distance education in the period of Pandemic. In the study conducted by Kör et al. (2013), it was concluded that using interactive materials such as animation, video, and simulation in distance education lessons will make students more efficient with the subject being remarkable.

According to the third sub-dimension of the study, they expressed that the motivation related to distance education decreased in the pandemic period in the majority of students at the university. When Sarıtaşand Barutçu (2020) examined the sub-dimensions of students' online teaching readiness in their study, it was seen that Horzum and Çakır (2015) had the lowest average of online learning control in their study.

Based on the results obtained from this study, the following suggestions can be made;

As we are in the pandemic period, students' opinions were received within the scope of the lectures given by a single lecturer at a single university. However, the opinions of students who take courses from different faculty members studying at different universities can be taken, associated, and compared.

Opinions of university students regarding distance education can be obtained by taking into consideration the study settlements.

The efficiency of distance education activities, the degree of student satisfaction and the difficulties experienced by learners should be explored.

It is recommended that universities' remote infrastructure systems are constantly updated for theory courses during the pandemic processand that equal opportunities are created for students with fewer opportunities.

It can increase the efficiency of the courses by providing in-service trainingabout the distance education system to faculty members. 
Quantitative research and relational screening research can be done to reach large kits.

Success and motivation can be increased by providing students with information training on distance education.

\section{References}

Akdemİr, Ö. (2011). Yükseköğretimimizde uzaktan eğitim. Yükseköğretim ve Bilim Dergisi, 1(2), 69-71.

Aldemir, C., ve Avşar, M.N. (2020) Pandemi Döneminde Dijital Vatandaşlık Uygulamaları. Avrasya Sosyal ve Ekonomi Araştırmaları Dergisi, 7(5), 148-169.

Aslan, R. (2020). Tarihten Günümüze Epidemiler, Pandemiler ve Covid-19. Ayrıntı Dergisi, 8(85).

Berigel, M. (2017). Quality and Cost/Benefit Analysis of Distance Education: A Case Study at Karadeniz Technical University. Mediterranean Journal of Social \& Behavioral Research, 1(1), 22-29.

Brooks, S. K., Smith, L. E., Webster, R. K., Weston, D., Woodl, L., Hall, I., \& Rubin, G. J. (2020). The impact of unplanned school closure on children's social contact: rapid evidence review. Euro Surveilliance, 25(13).http://doi.org/10.2807/1560- 7917.ES.2020.25.13.2000188

Cabı, E., ve Ersoy, H. (2017). Yükseköğretimde Uzaktan Eğitim Uygulamalarının İncelenmesi: Türkiye Örneği. Journal of Higher Education \& Science/Yüksekögretim ve Bilim Dergisi, 7(3).

Çetin, c., ve Özlem, A. N. U. K.(2020) Covıd-19 pandemi sürecinde yalnızlık ve psikolojik dayanıklılık: bir kamu üniversitesi öğrencileri örneklemi. Avrasya Sosyal ve Ekonomi Araştırmaları Dergisi, 7(5), 170-189.

Erarslan, Ö.(2014), Üniversite Öğrencilerinde Psikolojik Sağlamlık ile Depresif Belirtiler ve Yaşam Memnuniyeti Arasındaki İlişkide Benlik Saygısı, Pozitif Dünya Görüşü ve Umudun Aracı Rolünün İncelenmesi, Hacettepe Üniversitesi Sosyal Bilimler Enstitüsü, Psikoloji Ana Bilim Dalı, Klinik Psikoloji Bilim Dalı, Ankara: 44-61.

Karasar, N. (1998). Bilimsel araştırma yöntemleri (8. basım). Ankara: Nobel Yayın Dağıtım.

Kör, H.,Çataloğlu, E., \& Erbay, H. (2013). Uzaktan ve örgün eğitimin öğrenci başarısı üzerine etkisinin araştırılması.

Owusu-Fordjour, C., Koomson, C., \& Hanson, D. (2020).The impact of Covid-19 on learning- the perspective of the Ghanaian student. European Journal of Education Studies, 7(3), 88-101. http://doi.org/10.5281/zenodo.3753586

Sahu, P. (2020). Closure of universities due to coronavirus disease 2019 (COVID-19): Impact on education and mental health of students and academic staff. Cureus, 2019(4), 4-9. http://doi.org/10.7759/cureus.7541

Sarıtaş, E., ve Barutçu, S.(2020) Öğretimde dijital dönüşüm ve öğrencilerin çevrimiçi öğrenmeye hazır bulunuşluğu: Pandemi döneminde Pamukkale Üniversitesi öğrencileri üzerinde bir araştırma. Internet Uygulamaları ve Yönetimi Dergisi, 11(1), 5-22.

Telli, S. G.,veAltun, D. (2020). Coronavirüs ve çevrimiçi (online) eğitiminönlenemeyen yükselişi. Üniversite Araştırmaları Dergisi, 3(1), 25-34.

Tuncer, M. ve Tanaş, R. (2011). Akademisyenlerin Uzaktan Eğitim Programlarına Yönelik Görüşlerinin Değerlendirilmesi (Fırat ve Tunceli Üniversiteleri Örneği). İlköğretim Online Dergisi, 10(2), 776-784.

Tuncer, M.,\& Bahadır, F. (2017). Uzaktan Eğitim Programlarının Bu Programlarda Öğrenim GörenÖğrenci Görüşlerine Göre Değerlendirilmesi. Evaluation, 1(2).

Yıldırım, A., ve Şimşek, H. (2013). Sosyal bilimlerde nitel araştırma yöntemleri.(9. Genişletilmiş Baskı) Ankara: Seçkin Yayınevi.

Yildiz, G., \& Kilic Cakmak, E. (2021). Investigating the Distance Education Process According to the Demographic Characteristics of the Notary and the Notary Employee. Contemporary Educational Technology, 13(2), ep293. https://doi.org/10.30935/cedtech/9583

YÖK (2020b).Koronavirüs (Covid-19) bilgilendirme notu: 1. Erişim tarihi: 16.04.2020 Erişim adresi: https://www.yok.gov.tr/Sayfalar/Haberler/2020/coronavirus_bilgilendirme_1.aspx 